\title{
Benefit of E-Commerce for Travel and Tourism Industry
}

\author{
S Wiganepdo ${ }^{1}$, M S Dwintanissa ${ }^{2 *}$ \\ \{swiganepdo@email.unikom.ac.id ${ }^{1}$, medinasyafirad@mahasiswa.unikom.ac.id ${ }^{2}$ \} \\ Financial and Banking Department ${ }^{1}$, Department of Japanese Language and Literature ${ }^{2}$, \\ Universitas Komputer Indonesia, Bandung, Indonesia

\begin{abstract}
The purpose of this study is to facilitate tourists who want to visit tourist attractions with affordable facilities and costs. The preparation of this scientific work uses a method of deduction research, namely ways to make conclusions based on logical writing and obtained from the progress of application media technology that presents information about the facilities and infrastructure of tourist attractions that are currently in demand by tourists. The expected results of the many tourist destinations in Japan can provide business opportunities for travel entrepreneurs to further develop their businesses and simultaneously introduce tourist attractions in Japan to the international world. We know that the tourism sector has a vital role in economic growth in a country. The facilities offered in this tourism business are expected to attract more foreign tourists. Tourists can enjoy comfortable travel facilities, such as lodging facilities, travel fees, and tickets and treated to natural and cultural beauty typical of Japan. This opens up more promising business opportunities in the field of travel.
\end{abstract}

Keywords : facilitate tourists, application, and tourism business.

\section{Introduction}

In this increasingly modern era, e-commerce generates new business opportunities for international travel and the tourism industry. Tourism agencies and Internet companies join forces to open up potential markets created by e-commerce. Businesses have improved services internationally by registering with online travel agents, online advertising agencies, and reservation systems between organisations. In addition, many businesses have developed websites that offer online planning, ordering, and payment services to increase consumer convenience [1]. The tourism sector has a vital role in economic growth in a country. There are so many conveniences that will be obtained in this tourism business and are expected to attract more foreign tourists. From Forester's research on online retail reports, e-commerce has experienced very rapid growth every year as in 2012 as much as $28 \%$. Moreover, there was the fact that digital consumers spent US \$ 1.46 billion [2]. The rapid growth in the number of tourists seeking information and making reservations online using the internet proves that the popularity of the Internet among tourists [3]. In 2013, there were 2.8 billion internet users from all over the world [4]. Japan's modern domestic travel and tourism industry offers a variety of unique cultures because Japan's domestic travel has been Japan's social concern for more than two decades. From the source obtained, Statista, Japan's e-commerce market is known as one of the largest in the world, and in 2015 the purchase of retail e-commerce was the only US $\$ 80$ billion and $40 \%$ of Japanese tourists had booked travel using the internet. So when entering the market as big as this, it is good to do research first [5].

The tourism industry relies heavily on developing new facilities to distribute marketing information-based travel products and services to customers according to their wishes [6]. According to the E-Commerce Visa Tracking Survey conducted in May 2008, 80\% of internet users surveyed in the Asia Pacific conducted online transactions, spending an average of more than US \$3,000 in the past 12 months. They also spend the most on travel agents, with an average purchase of US \$ 812 [7]. Travel items include flight and train tickets, hotel accommodation and travel packages. This survey explains the number of online tourism and 
online shopping in the Asia Pacific [8]. The development of internet services by business people in the tourism industry helps with the goal of e-tourism opportunities for fast communication and global access with minimal costs [9]. With the advancement of ecommerce technology, the increasing number of tourists who use the internet to find a variety of tourist information and to make online transactions. According to the American Travel Industry Association, $67 \%$ of US tourists have used the Internet to search for tourist information or check flight prices or schedules. There are even $41 \%$ of US tourists have booked several aspects of their travel through online media [10].

E-commerce has become one of the shopping methods that are liked by many people around the world because they enjoy the convenience and convenience [11].

They can buy products or services from home at any time of the day or night. Also, they can buy their needs quickly, comfortably, and a secure payment system by transferring funds online. Therefore, consumers can save more time and money when buying their needs easily on online sites. The purpose of this research is to provide information about the ease and benefits of e-commerce for tourists who want to visit tourist attractions in Japan with affordable facilities and costs, as well as providing a different travel experience by introducing more Japanese culture.

\section{Material and Methods}

This research was conducted by deduction method to make conclusions based on the advancement of e-commerce technology that provides convenience to consumers to find information about tourist facilities and infrastructure that are currently in demand by tourists. And they can also determine the costs that will be incurred at that time.

\section{Results and Discussion}

To attract consumers who want a vacation to access online sites, the agent must upload and explain information about the travelling services that will be offered. For example, ecommerce businesses that offer travel experiences to Japan are different from others. With Japanese locals, foreign tourists who come will get authentic experiences around their homes. At the same time, local people benefit directly from the increasing number of foreign tourists, such as additional income and also they can promote cultural characteristics found in their hometown. In addition, e-commerce consumers can easily find flight tickets and lodging at a low cost. They can also see what facilities are available at the inn. Reservations can be made at any time and anywhere through internet access using any electronic device, practically without having to go to a regular travel agent and will not require a lot of time.

The payment can also use ATM transfer transactions, Internet Banking, Mobile Banking, and SMS Banking. With e-commerce, consumers will feel satisfied because of the fast response and various conveniences that have been given. In Huber's main menu view, users can see several posters displaying various things that can be done with people who work with this site. At the top right, there is an option for users to log in first. After completing the profile, users can start sketching trips to tourist attractions throughout Japan shown in Fig 1. 


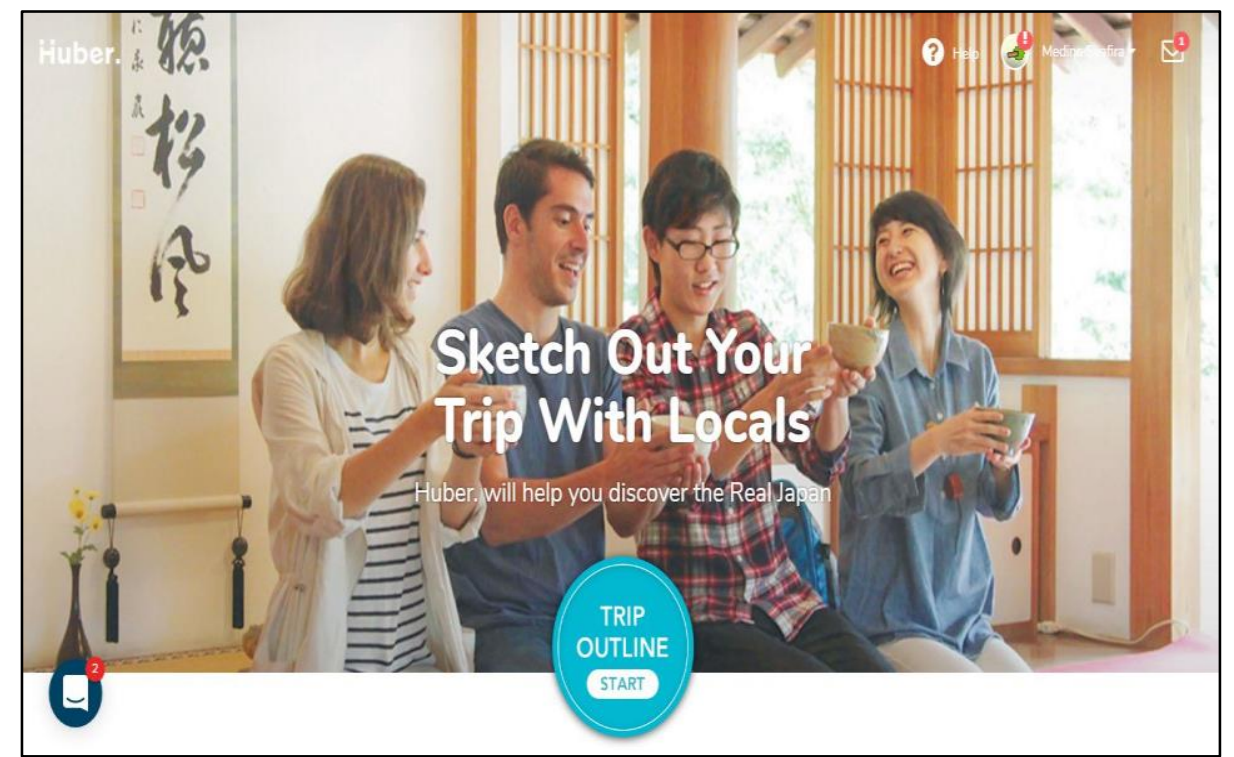

Fig 1. Huber's Main Menu. This Figure was adopted www. huber-japan.com , was taken on March 10, 2019.

First, Huber will give 11 questions based on the type of tour you are looking for. User answers will be sent to some of the local guides that are most suitable for providing the type of tour sought. Then the page will display local guides who have compiled plans for the tours they can offer and send them back to users Figure 2 and There are also profiles of each guide and the price they offer and the length of time for the tour. After that, choose the preferred local guide! With a system like this, making tourists more comfortable to explore the attractions they will visit and will not be confused looking for fun places in Japan because here the local guide has designed the tour they want. Shown in Fig 2 and fig 3.

\section{http://huber-japan.com}

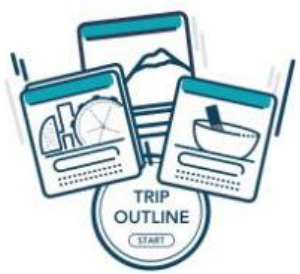

Answer 11 questions

to get combinations of local guides and their ideas.

\section{How It Works}

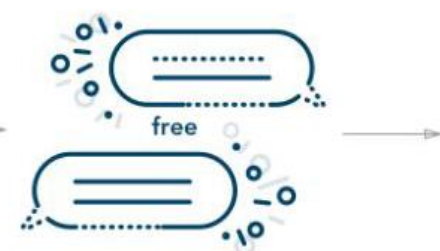

$$
\begin{aligned}
& \text { Discuss the ideas } \\
& \text { to make your own trip } \\
& \text { with the local. }
\end{aligned}
$$

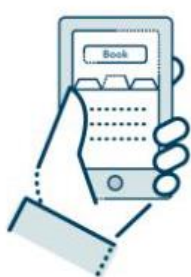

Book the local after Planning in chat

Our Booking System $\rightarrow$

Fig 2. Step Start the Journey. This Figure was adopted www. huber-japan.com, was taken on March 10, 2019. 


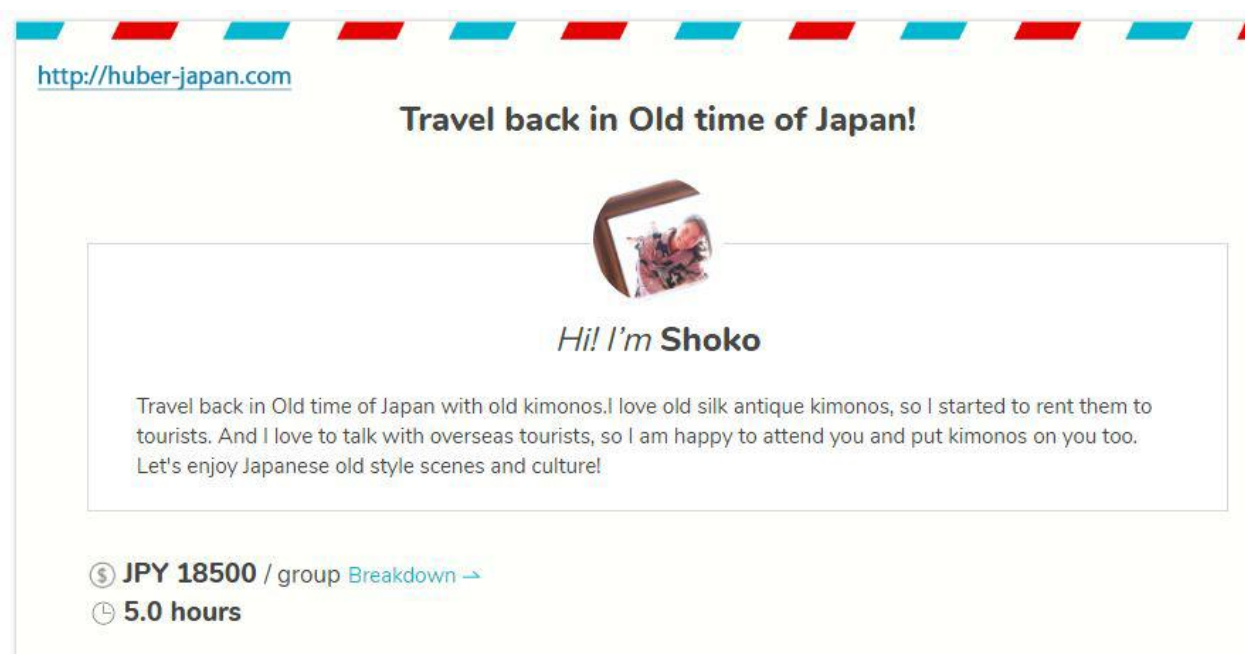

Fig 3. Guide Profile, This Figure was adopted www. huber-japan.com, was taken on March 10, 2019

When the user has chosen the appropriate local guide, the guide will send a "travel offer" with the itinerary and the total price they have to pay, then complete the booking. Users can start chatting with their chosen guide about the proposed plan, get more in-depth with what they want to do. This Huber the chat application is the best way to communicate from a cell phone and make it easier for users and guides to meet after they are in Japan. In this way, each tour is unique and tailored to the wishes of tourists shown in Fig 4.

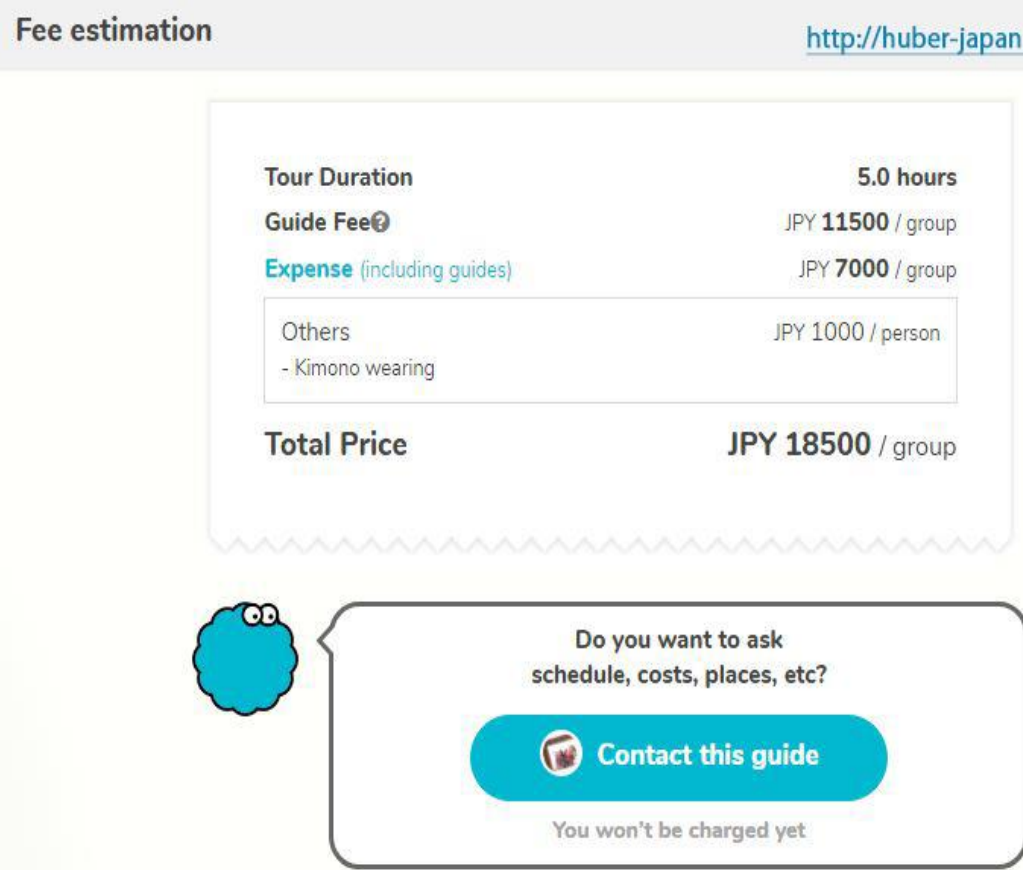

Fig 4. Fee Estimation, This Figure was adopted www. huber-japan.com , was taken on March 10, 2019.

After tourists have got the tourist destination they want, then what they need is an airline ticket and lodging that is close to their destination. To purchase airline tickets and lodging, I recommend Tiket.com site. Here I am researching Tiket.com site because this site has a complete airline. Besides, ticket prices and hotels are also very affordable for foreign tourists who will travel but only have a small budget. On the main menu display, there are several submenus; on this page, users can see various kinds of promos offered by this site. Before starting to search for flight tickets, the user must log in first such as filling in the full name, email and telephone number. After that, the user can directly choose the flight from the place of origin to Japan. Also, specify the date of departure and date when we will go home. Then 
the site will display various types of airlines, flight times, and ticket prices from cheap to expensive. I research on Tiket.com because this site has many advantages, besides the complete airline, the price is relatively cheap, and Tiket.com offers many promos for its users. This makes it easier for users to find flight tickets at prices that are within budget without having to search for various other internet sites shown in Fig 5.

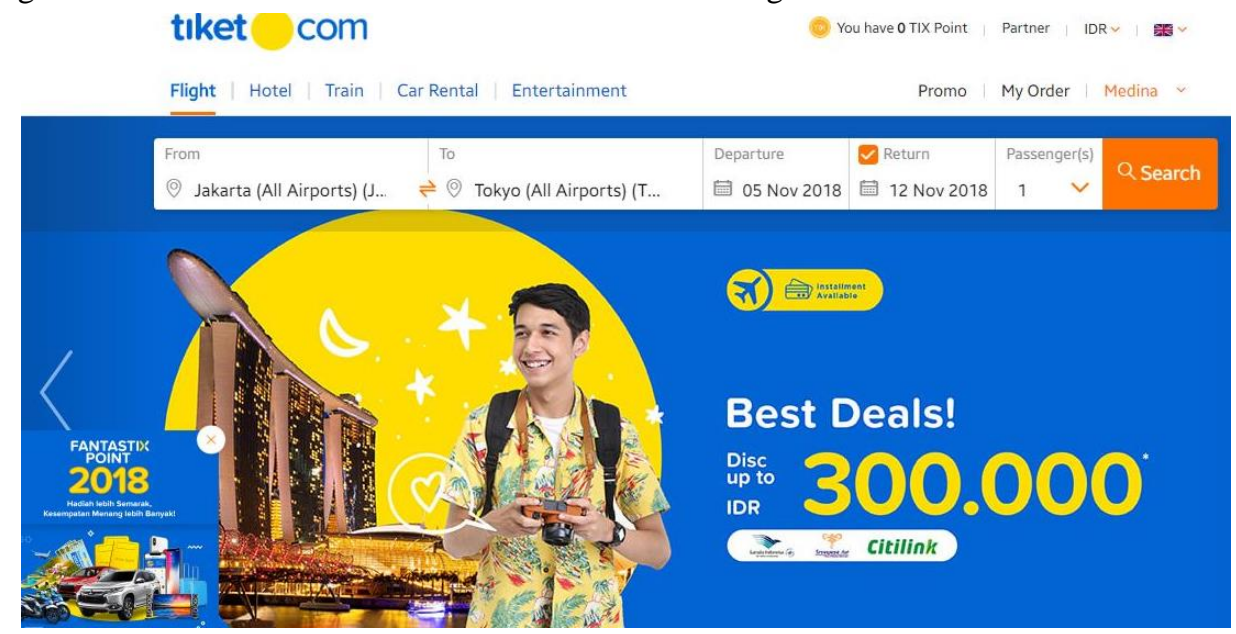

Fig 5. Tiket.com's Main Menu, This Figure was adopted www.tiket.com, was taken on March 10, 2019.

If you have finished choosing the flight ticket, the user can immediately switch to the hotel page. Here are some options listed; the user must fill in the destination, check-in and, check-out. For hotel prices, users can also adjust the price range to a minimum. Then a page will appear showing the hotel with various star ratings and information about all the facilities available at the hotel. In this study, we developed the ease of information technology in the tourism industry and made users satisfied with all the information provided shown in Fig 6.

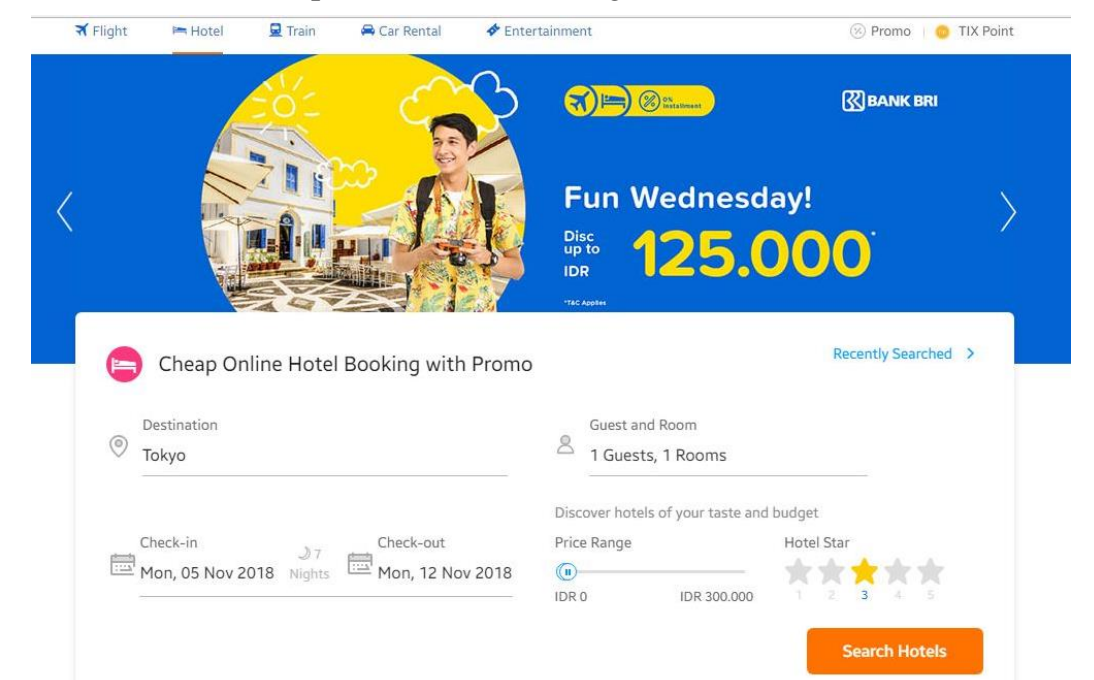

Fig 6. Hotel Menu This Figure was adopted www.tiket.com, was taken on March 10, 2019.

When everything is finished, the site will display the order details and the total price that the user must pay. Here the user must re-check the personal data information; then the user can choose the available payment method. Then, choose the transfer payment method via ATM, Internet Banking, SMS Banking or Mobile Banking. After making payment and payment has been received by Tiket.com, users will automatically receive e-tickets or vouchers via email. Then print the e-ticket to show at check-in or for ticket exchange. Do not forget to bring the appropriate identity card by filling in the data when making the payment. From observations, Tiket.com does not provide flight ticket purchase services accompanied by hotel room bookings. So users must order and pay for airline tickets and hotel rooms separately. Although simple and does not require a lot of time but for users, this is less efficient shown Fig 7. 


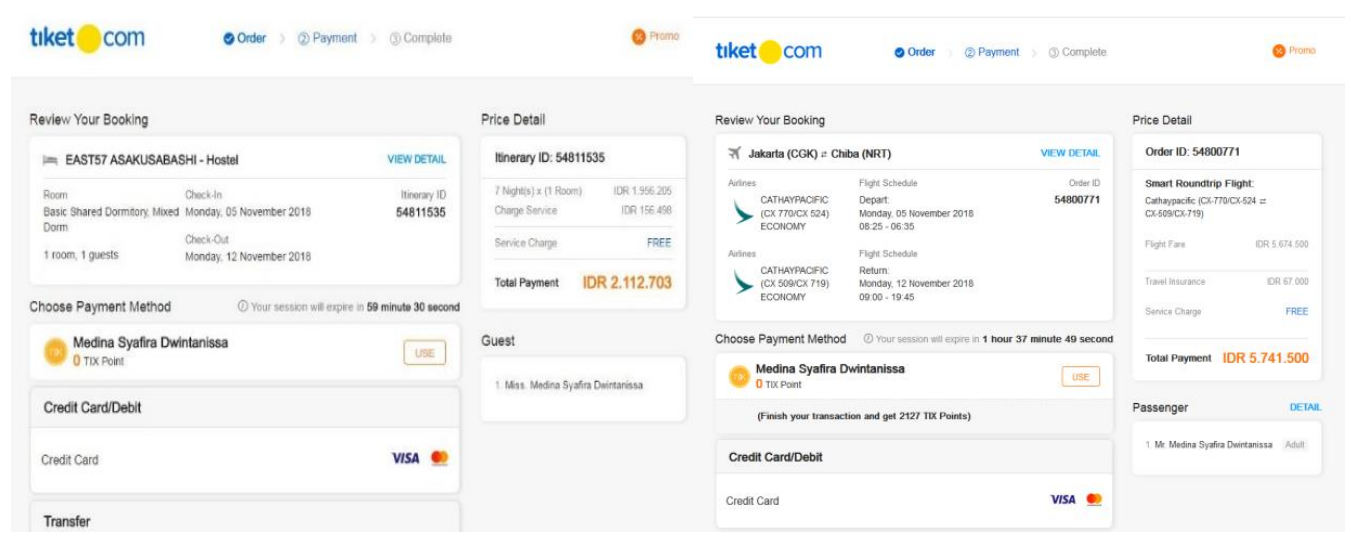

Fig 7. Flight Ticket Payment Method and Hotel Payment Method, This Figure was adopted www.tiket.com , was taken on March 10, 2019.

\section{Conclusion}

The development of technological advances makes it easy for everyone, especially in the ecommerce business for travelling. Consumers feel more comfortable doing online transactions because they can order airline and hotel tickets anytime and anywhere without requiring a lot of time. With e-commerce, all can be done quickly and efficiently. Consumers can also see ratings and information about available facilities. So they are not worried after choosing airplane and hotel tickets because all information is clearly illustrated. And of course, the 24hour Customer Service is ready to help when something happens.

\section{Acknowledgements}

With the completion of this scientific work, we would like to thank Allah SWT for his blessings and gifts so that we can carry out and complete this scientific work. Thank you also to parents and friends for helping us while working on this scientific work. Also, those who have supported this research process.

\section{References}

[1] Mamaghani F.: Impact of e-commerce on travel and tourism: An historical analysis. International Journal of Management, 26(3), pp. 365 (2009).

[2] Soegoto E S.: Entrepreneurship Menjadi Pebisnis Ulung Panduan bagi Pengusaha, Calon Pengusaha, Mahasiswa, dan Kalangan Dunia Usaha (2014).

[3] Fernández-Cavia J, Rovira C, Díaz-Luque P, \& Cavaller V.: Web Quality Index (WQI) for official tourist destination websites: Proposal for an assessment system. Tourism Management Perspectives, 9, pp. 5-13 (2014).

[4] Internet World Stats Usage and population statistics: Top 20 countries with the highest number of the Internet users (2013).

[5] Creighton M.: Consuming rural Japan: The marketing of tradition and nostalgia in the Japanese travel industry. Ethnology, pp. 239-254 (1997).

[6] Zou Z .: E-commerce and information technology in hospitality and tourism. Canada: Delmar. Visa. Visa survey reveals 80 percent of Asia Pacific Internet users go online to shop (2008).

[7] Hung Y C, Yang Y L, Yang H E, \& Chuang Y H.: Factors affecting the adoption of e-commerce for the tourism industry in Taiwan. Asia Pacific Journal of Tourism Research, 16 (2011).

[8] Buhalis D.: The future of eTourism intermediaries. Tourism Management, 23, pp. 207-220 (2001).

[9] Litvin S W, Goldsmith R E, \& Pan B.: Electronic word-of-mouth in hospitality and tourism management. Tourism management (2008).

[10] Soegoto E S, \& Eliana E.: E-Commerce and Business Social Media Today. In IOP Conference Series: Materials Science and Engineering, 407(1), p. 012034. 